\title{
BDNF/TrkB Signaling Augments Smooth Muscle Cell Proliferation in Pulmonary Hypertension
}

\author{
Grazyna Kwapiszewska, ${ }^{* \dagger}$ Karolina Chwalek, ${ }^{*}$ \\ Leigh M. Marsh, ${ }^{\dagger}$ Malgorzata Wygrecka, ${ }^{\ddagger}$ \\ Jochen Wilhelm, ${ }^{*}$ Johannes Best, ${ }^{*}$ \\ Bakytbek Egemnazarov, ${ }^{\dagger}$ Friederike C. Weisel, ${ }^{*}$ \\ Sarah L. Osswald, ${ }^{*}$ Ralph T. Schermuly, ${ }^{*}$ \\ Andrea Olschewski, ${ }^{\dagger}$ Werner Seeger, ${ }^{*}$ \\ Norbert Weissmann, ${ }^{*}$ Oliver Eickelberg, ${ }^{\S}$ and \\ Ludger Fink ${ }^{* \Uparrow}$

\begin{abstract}
From the Departments of Internal Medicine $I^{*}$ and Biochemistry, ${ }^{\ddagger}$ Universities of Giessen and Marburg Lung Center (UGMLC), Justus-Liebig University, Giessen, Germany; the Ludwig University Munich and Helmholtz Center Munich, Institute of Lung Biology and Disease (iLBD), Neuherberg/Munich, Germany; and the Institute of Pathology and Cytology," Wetzlar,
\end{abstract} \\ Boltzmann Institute for Lung Vascular Research, ${ }^{\dagger}$ Graz, Austria; \\ the Comprehensive Pneumology Center, ${ }^{\S}$ Ludwig Maximilians \\ Germany
}

Pulmonary hypertension (PH) is a life-threatening disorder that is characterized by pulmonary arterial smooth muscle cell (PASMC) hyperplasia. Until now, little was been known about early changes that underlie the manifestation of PH. To characterize these early changes, we performed whole-genome microarray analysis of lungs from mice exposed to either 24 hours hypoxia or normoxia. TrkB, a member of the tyrosine kinase receptor family, and its ligand, brainderived neurotrophic factor (BDNF), were strongly up-regulated in hypoxic mouse lungs, as well as in arteries of patients suffering from idiopathic pulmonary arterial hypertension (IPAH). BDNF stimulation of PASMC in vitro resulted in increased proliferation, TrkB and ERK1/2 phosphorylation, and nuclear translocation of the transcription factor early growth response factor 1 (Egr-1). In addition, increased Egr-1 expression was observed in idiopathic PAH lungs. The pro-proliferative effect of BDNF was attenuated by TrkB kinase inhibitor (K252a) or ERK1/2 inhibitor (U0126) pretreatment, and by knocking down Egr-1. Consequently, we have identified the BDNF-TrkBERK1/2 pathway as a proproliferative signaling pathway for PASMC in PH. Interference with this pathway may thus serve as an attractive reverse remodeling approach. (AmJ Patbol 2012, 181:2018-2029; http://dx.doi. org/10.1016/j.ajpath.2012.08.028)

Pulmonary hypertension $(\mathrm{PH})$ is a life-threatening disease characterized by a distinct and persistent elevation of pulmonary arterial pressure, which ultimately results in right ventricular failure and death. ${ }^{1,2} \mathrm{PH}$ manifests itself in various diseases, including chronic obstructive lung disease and chronic thromboembolism, but also rare idiopathic and familial forms exist. ${ }^{3} \mathrm{PH}$ has a multifactorial pathogenesis, with both vasoconstriction and structural remodeling of the pulmonary vessels contributing to disease progression. ${ }^{3}$ Structural changes underlying the remodeling processes include abnormal endothelial cell proliferation, as well as increased migration and proliferation of smooth muscle cells (SMC) and fibroblasts. ${ }^{4}$ Enhanced proliferation of pulmonary arterial SMCs (PASMC) can arise from a dysfunctional bone morphogenic protein receptor II; however, these mutations occur in only $10 \%$ to $40 \%$ of all idiopathic pulmonary arterial hypertension (IPAH) patients. ${ }^{5,6}$ Additionally, changes in growth factor production or receptor levels have been shown to influence the development of $\mathrm{PH}$. These include; platelet-derived growth factor (PDGF), basic fibroblast growth factor (bFGF), and epidermal growth factor (EGF), ${ }^{7-10}$ which act as strong mitogens and chemoattractants for pulmonary SMCs. ${ }^{11}$ Additionally, up-regulation of the tyrosine receptor kinases PDGFR $\alpha$ and $\beta$ has been observed in lambs with chronic intrauterine pulmonary hypertension ${ }^{12}$ and already first clinical evidence for

Supported by a faculty grant (Anschubfinanzierung) from the JustusLiebig University School of Medicine, Giessen, Germany (G.K., K.C.); German Research Foundation (DFG, SFB-547; to R.T.S., W.S., N.W., L.F.); Excellence Cluster 147 "Cardiopulmonary System" (G.K., M.W., W.S., N.W.), the University Medical Center Giessen and Marburg (G.K., M.W.)

Accepted for publication August 23, 2012.

Supplemental material for this article can be found at http://ajp. amjpathol.org or at $h$ ttp://dx.doi.org/10.1016/j.ajpath.2012.08.028.

Address reprint requests to Grazyna Kwapiszewska, Ph.D., Ludwig Boltzmann Institute for Lung Vascular Research, c/o ZMF; Stiftingtalstrasse 24, 8010 Graz, Austria. E-mail: Grazyna.Kwapiszewska@Ivr. lbg.ac.at. 
successful treatment of PH by PDGFR interference was presented. ${ }^{13}$

Another well-recognized stimulus of pulmonary vasoconstriction and consequent vascular remodeling is chronic hypoxia. ${ }^{14-16}$ In response to low alveolar oxygen, voltage-gated potassium channels are down-regulated, resulting in depolarization of SMCs, subsequent $\mathrm{Ca}^{2+}$ influx, and increased vasoconstriction. ${ }^{17,18}$ Other important effectors for hypoxic remodeling are hypoxia-inducible transcription factors (HIFs), which are known to induce a number of genes under hypoxic conditions. ${ }^{19-21}$

In a previous study, we have demonstrated genes regulated after prolonged hypoxia exposure in mouse model of hypoxia-induced $\mathrm{PH} .{ }^{22}$ However, early genetic changes in response to hypoxia, representing possible trigger mechanisms, leading to vascular remodeling remain poorly understood. Therefore, we have undertaken whole-genome microarray analysis to investigate transcriptional changes occurring in the lung of the hypoxic mouse model during onset of pulmonary hypertension after only 24 hours of hypoxic exposure. We identified the Ntrk2 gene encoding tyrosine-related kinase B (TrkB), a member of the tyrosine kinase receptor family, as strongly up-regulated in hypoxic mouse lungs. Against the background that i) in our study, TrkB levels were also elevated during sustained hypoxic exposure, ii) TrkB expression has been previously shown to be present on human and rat vascular SMCs and endothelial cells, ${ }^{23,24}$ and iii) other tyrosine kinases have previously been implicated in the development of $\mathrm{PH}$, we have studied in more detail the role of TrkB in vascular remodeling.

\section{Materials and Methods}

\section{Exposure to Chronic Hypoxia}

Eight-week-old male BALB/c mice were exposed to normobaric normoxia [fraction of inspired oxygen $\left(\mathrm{FiO}_{2}\right)$ of 0.21 ] and to normobaric hypoxia $\left(\mathrm{FiO}_{2}\right.$ of 0.10$)$ for 1,7 , and 21 days, respectively. Isolation and preparation of mouse lungs have been described in detail previously. ${ }^{22,25}$ The Egr-1 ${ }^{-1-}$ animals were a kind gift of Patrick Charnay (Ecole Normale Supérieure, IBENS, Paris Cedex, France). The $\mathrm{BDNF}^{+/-}$and $\mathrm{TrkB}^{+/-}$mice were purchased from Jackson Laboratories (Bar Harbor, ME).

\section{Microarrays and Data Analysis}

Total RNA was isolated using the RNeasy Mini kit (Qiagen, Hilden, Germany) from lung homogenate of 18 BALB/c mice per group exposed for 24 hours to normobaric normoxia $\left(\mathrm{FiO}_{2}\right.$ of 0.21$)$ and to normobaric hypoxia $\left(\mathrm{FiO}_{2}\right.$ of 0.10$)$. RNA from 6 mice each was used as a pooled sample for labeling and hybridization. Labeled cDNA was generated using Superscript II to reverse transcribe $50 \mu \mathrm{g}$ of RNA incorporating of Cy3- and Cy5-dCTP (all reagents from Invitrogen, Karlsruhe, Germany). The labeled cDNA was purified using a PCR purification kit (Qiagen). The volume of elute was reduced from $50 \mu \mathrm{L}$ to $\sim 10 \mu \mathrm{L}$ using a centrifugal vacuum concentrator. Competitive hybridizations (hypoxia/normoxia) were per- formed for 18 hours in UltraHyb buffer (Ambion, Austin, $\mathrm{TX}$ ) at $42^{\circ} \mathrm{C}$ on 60mer oligonucleotide microarrays (MWG 30K mouse) using the GeneTAC hybridization station (PerkinElmer, Waltham, MA). The data were analyzed using the limma package in $\mathrm{R}^{26,27}$ Intensity values were background subtracted; log ratios were normalized using a loess correction on the MA-plot values. ${ }^{27}$ Regulated genes were filtered by using moderated t-statistics and adjusting the false discovery rate at 10\%. ${ }^{27}$ Experimental design is provided in Supplemental Figure S1 (available at http://ajp.amjpathol.org). Pathways were analyzed using PathwayExpress and OntoExpress of the OntoTools. ${ }^{28}$

\section{Isolation of Mouse Pulmonary Arteries}

Mice exposed to hypoxia $(n=10)$ or normoxia $(n=10)$ for 21 days were euthanized with ketamine $(6 \mathrm{mg} / 100 \mathrm{~g})$ and xylazine ( $1 \mathrm{mg} / 100 \mathrm{~g}$ ) intraperitoneally. Major pulmonary arteries were dissected for isolation of mRNA and expression analysis.

\section{Rat Monocrotaline and Su5416 Models of Pulmonary Arterial Hypertension}

Lung homogenate samples from the monocrotalineinduced as well as the Su5416 rat model ${ }^{29}$ of pulmonary hypertension were obtained as described previously. ${ }^{25,30}$

\section{Patient Characteristics and Measurements}

Samples from human lung tissue were obtained from five donors and five IPAH patients undergoing lung transplantation as described previously. ${ }^{31}$ Patient characteristics are provided in previous publications. ${ }^{31,32}$

\section{Laser-Assisted Microdissection}

Microdissection of pulmonary arteries (40 vessels per animal with a diameter of 100 to $250 \mu \mathrm{m}$, four animals each) was performed on mounted cryosections using the Laser Microbeam System (P.A.L.M., Bernried, Germany) as described in detail previously. ${ }^{22}$

\section{Immunohistochemistry}

All immunohistochemical experiments were performed on paraffin-embedded serial slides. All antibodies were diluted (1:100) in ChemMate Antibody Diluent, (Dako, Glostrup, Denmark): anti-TrkB, anti-BDNF, anti-NT-4/5, anti-Egr-1 (all from Santa Cruz Biotechnology, Santa Cruz, CA). After overnight incubation in a humid chamber, slides were washed three times in Tris-buffered saline ( $\mathrm{pH} 7.4$ to 7.6) and incubated for 45 minutes with corresponding secondary antibodies conjugated with alkaline phosphatase (Rockland, Gilbertsville, PA) at a 1:250 dilution. Negative controls were prepared with the omission of the primary antibody. 


\section{Immunofluorescence Staining}

For immunofluorescence analysis, untreated or BDNF treated PASMC were grown on glass slides and fixed for 5 minutes in cold methanol. Cells were then blocked for 2 hours with 3\% bovine serum albumin in Tris-buffered saline, and incubated overnight at $4^{\circ} \mathrm{C}$ with anti-TrkB, anti-BDNF, or anti-Egr-1 antibody (all from Santa Cruz Biotechnology). Slides were then incubated with antirabbit IgG-Alexa 555 and mounted with fluorescence Vectashield Mounting Medium (Vector Laboratories, Burlingame, CA). To investigate proliferation of unstimulated or BDNF-stimulated human PASMC, cells were permeabilized for 5 minutes with $0.25 \%$ Triton X-100 in Tris-buffered saline, incubated with a mouse anti-human Ki-67 antibody (Santa Cruz Biotechnology), followed by incubation with fluorescein isothiocyanate-labeled secondary antibody (Dianova, Hamburg, Germany). Cell nuclei were counterstained with DAPI (Sigma-Aldrich, Munich, Germany). For microscopic inspection, a Leica DMR microscope (Leica Microsystems, Wetzlar, Germany) was used.

\section{Western Blot Analysis and Kinase Activity}

Cell lysates from lung homogenates and PASMC were separated by $12 \%$ SDS polyacrylamide gel, followed by electrotransfer to a $0.45-\mu \mathrm{m}$ polyvinylidene difluoride membrane (ImmobilonTM-P; Millipore, Bedford, MA). After blocking with 5\% nonfat dry milk in Tris-buffered saline + $0.1 \%$ Tween 20 , the membrane was incubated overnight at $4^{\circ} \mathrm{C}$ with one of the following primary antibodies: antiBDNF, anti-TrkB, anti-Egr-1 (all from Santa Cruz Biotechnology), or anti- $\beta$-actin (Biozol, Eching, Germany). After incubation for 1 hour with horseradish peroxidase-labeled secondary antibodies (Pierce Biotechnology, Rockford, IL; all at 1:3000 in blocking solution) signals were visualized by the ECL detection system (Pierce Biotechnology). For phosphorylation study, a rabbit antiphospho-TrkB(Tyr516)/A(Tyr490) (Santa Cruz Biotechnology), or a rabbit anti-phospho-p42/44 MAP kinase antibody (Cell Signaling Technology, Boston, MA) was applied. Blots were stripped and reprobed using a rabbit anti-TrkB (Santa Cruz Biotechnology), or an anti-p42/44 MAP kinase antibody, respectively (Cell Signaling Technology).

\section{Quantitative Real-Time PCR}

RNA from laser-microdissected material was isolated by RNeasy Micro Kit (Qiagen), whereas RNA from lung tissues and cell culture experiments was isolated by RNeasy Mini Kit (Qiagen) according to the manufacturer's protocols. Quality and quantity of RNA was determined by $1.5 \%(\mathrm{~m} / \mathrm{v})$ agarose gel and UV absorbance (Nanodrop spectrophotometer; Thermo Scientific, Wilmington, DE). RNA was reverse transcribed using Moloney Murine Leukemia Virus Reverse Transcriptase (Applied Biosystems, Foster City, CA). Real-time PCR was performed in an ABI 7900HT Sequence Detection System (Applied Biosystems) using SYBR-Green I (Qiagen) as fluorogenic probe. Primer pairs were as follows, mouse: BDNF: forward, 5'-TTCGAGAGGTCTGACGACGAC-3', reverse, 5'-ACCCGGGAAGTGTACAAGTCC-3'; PBGD: forward, 5'-GGTACAAGGCTTTCAGCATCGC-3', reverse, 5'-ATGTCCGGTAACGGCGGC-3'; TrkB: forward, 5'GCAAACCAGAAAAGGCTAGAAATC-3', reverse, 5'TGTAAGCCACAAACTTTAAGCCG-3'; human: BDNF: forward, 5'-CAAGGCAGGTTCAAGAGGCT1-3', reverse, 5'CTGGACGTGTACAAGTCTGCG-3'; CCND1: forward, 5'CCGTCCATGCGGAAGATC-3', reverse, 5'-TAGTTCATGGCCAGCGGG-3'; Egr-1: forward, 5'-GTाTGCAGGAGCGATGAAC-3', reverse, 5'-CCGAAGAGGCCACAACACTT-3'; FN1: forward, 5'-CCGACCAGAAGTITGGGTTCT-3', reverse, 5'-CAATGCGGTACATGACCCCT-3'; PBGD: forward, 5'CCCACGCGAATCACTCTCAT-3', reverse, 5'-TGTCTGGTAACGGCAATGCG-3'; TrkB: forward, 5'-ACATTCCGTCACCTTGACTTGT-3', reverse, 5'-GGATGGATTAGCCTCTTGGAG-3'. Each gene was measured in duplicate in at least three independent experiments. The $\Delta \mathrm{C}_{\mathrm{T}}$ values $\left(\Delta \mathrm{C}_{\mathrm{T}}=\right.$ $\mathrm{C}_{\text {Treference }}-\mathrm{C}_{\text {Ttarget }}$ ) for each target gene were calculated using PBGD as the reference gene.

\section{Cell Culture}

Primary human PASMC were purchased from Lonza (Basel, Switzerland) or PromoCell (Heidelberg, Germany) or isolated from human pulmonary arteries from nontransplantable donor lungs, as well as from lungs explanted from IPAH patients. The purity of PASMC cultures was confirmed using indirect immunofluorescence antibody staining for smooth muscle-specific isoforms of $\alpha$-actin and myosin (minimum 95\% of cells stained positive) and lack of staining for von Willebrand factor. Recombinant human BDNF (R\&D Systems, Wiesbaden, Germany) was used at a final concentration of 5 or $10 \mathrm{ng} / \mathrm{mL}$, ERK $1 / 2$ kinase inhibitor U0126 (final concentration $20 \mathrm{mmol} / \mathrm{L}$ ) were obtained from Alamone Labs (Jerusalem, Israel) and Calbiochem (Darmstadt, Germany), respectively. The BDNF blocking antibody was purchased from Chemicon International (Temecula, CA; final concentration $2.5 \mu \mathrm{g} / \mathrm{mL})$.

\section{Electrophoresis Mobility Shift Assay}

The electrophoretic mobility shift assay was performed with nuclear extracts (Pierce Biotechnology) from human PASMC using the oligonucleotide probe (5'-GGATCCAGCGGGGGCGAGCGGGGGCGA-3') containing the Egr consensus sequence (Santa Cruz Biotechnology) as described previously. ${ }^{25}$

\section{Proliferation Assay}

Cell proliferation of PASMC was assessed by $\left[{ }^{3} \mathrm{H}\right]$-thymidine incorporation as described previously. ${ }^{31}$ For siRNA studies, proliferation was measured by bromodeoxyuridine incorporation according to the manufacturer's protocol (Roche, Mannheim, Germany). 


\section{Assessment of Apoptosis}

Identification of apoptotic cells after 1 and 24 hours of BDNF (10 ng/mL) treatment was performed using allophycocyanin-conjugated annexin $\mathrm{V}$ (Invitrogen), following the recommendations of the manufacturer. $\mathrm{Ne}$ crotic cells were excluded by counterstaining with 2 $\mu \mathrm{g} / \mathrm{mL}$ propidium iodide. Data were collected using a FACSCanto flow cytometer and analyzed using a FACSDiva software package (both from BD Biosciences, Heidelberg, Germany). A minimum of 10,000 cells were analyzed per sample. Gates based on forward and side scatter were set to eliminate cellular debris and cell clusters.

\section{Transfection with siRNA}

PASMC were transfected with small interference RNA (siRNA) at (100 nmol/L) using X-treme Gene siRNA Transfection Reagent (Roche) or Lipofectamine2000 (Invitrogen). Predesigned, commercially available siRNA against human Egr-1 (siGenomeSMART pool) was purchased from Dharmacon (Chicago, IL), TrkB (siGenomeSMART pool) from Dharmacon and Santa Cruz Biotechnology, siRNA against BDNF (Santa Cruz Biotechnology), control siRNA from Ambion. Knockdown efficiency was assessed 24 hours (Egr-1) or 72 hours (TrkB and BDNF) post transfection by real-time PCR.

\section{Statistical Analysis}

Bar charts show mean \pm SEM. Differences between more than two groups were assessed by analysis of variance followed by Dunnett's multiple-to-one comparison post hoc tests. All data that were subjected to statistical analysis were checked for normal distribution by quantilequantile plots. Where appropriate, the paired Student's $t$-test was performed. All experiments were designed with matched control conditions to enable statistical comparison. An asterisk indicates $P \leq 0.05$.

\section{Results}

\section{Hypoxia Array Data}

RNA expression profiles were compared from lung homogenates from mice exposed to normoxia or hypoxia for 24 hours using whole-genome microarray analysis. Under hypoxia, 918 genes were up-regulated and 648 genes were down-regulated (10\% false discovery rate). Among these genes, 99 were up- and 27 down-regulated by fold change $\geq 2$. Genes previously reported to be involved in hypoxic remodeling [ie, PDGFb, vascular endothelial growth factor (VEGF) c, and endothelin1 (Edn1)] revealed strong up-regulation following hypoxia exposure (Figure 1A). Several gene pathways were overrepresented in the candidate lists (Figure 1B). Of interest, genes involved in the MAPK signaling pathway revealed strong regulation, where the strongest induction was observed for Ntrk2/TrkB ( sevenfold up). Because tyrosine kinases have previously been implicated in the develop- ment of $\mathrm{PH}$, we therefore studied in more detail the role of TrkB in vascular remodeling.

We subsequently investigated the expression of TrkB at more time points by real-time PCR. Short exposure to hypoxia (24 hours) strongly induced TrkB expression, confirming the array data (Figure 1C). High levels of TrkB expression were maintained during prolonged exposure of mice to hypoxia (7 and 21 days). To localize the expression of TrkB and its ligands, BDNF and neurotrophin 4 (NT-4) in the lung parenchyma, immunohistochemical staining was performed. All three proteins localized to epithelial cells in the bronchial tree; however, TrkB and BDNF were also localized to the pulmonary vasculature as indicated by smooth muscle actin (SMA) staining of consecutive sections (Figure 1D; see also Supplemental Figure S2 at $h$ ttp://ajp.amipathol.org). Antibody specificity was assessed on BDNF and TrkB knockout mice tissues (see Supplemental Figure S3 at $h$ ttp://ajp.amjpathol.org). To determine TrkB- and BDNF-specific expression in $\mathrm{PH}$, we isolated major pulmonary arteries from mice exposed to either 21 days hypoxia or normoxia. Similar to the induction observed in whole lungs, increased expression of TrkB was observed in pulmonary arteries (Figure 1E). Interestingly, increased BDNF expression was also detected (Figure 1E). Laser-microdissection of intrapulmonary arteries in combination with real-time PCR showed similar induction of TrkB and BDNF expression under hypoxic conditions (Figure 1F). Expression of TrkB and $B D N F$ by SMC was confirmed by real-time PCR (Figure $1 G$ ), and immunofluorescence staining of isolated mouse PASMC (Figure 1H) and microvascular pulmonary SMCs (see Supplemental Figure S4A at http://ajp.amjpathol. org). Of note, in normoxic conditions in mouse primary PASMC TrkB expression levels were on the limit of detection, whereas $B D N F$ was abundantly expressed. Hypoxia exposure led to increased expression of TrkB in mouse PASMC (see Supplemental Figure S4B at $h t t p: / /$ ajp.amjpathol.org). Specificity of immunofluorescence staining was assessed by using siRNA to knockdown TrkB and BDNF expression (see Supplemental Figure S5, $\mathrm{A}$ and $\mathrm{B}$, at http://ajp.amjpathol.org).

\section{Regulation of TrkB and BDNF in Monocrotaline and Su5416-Treated Rats}

To determine whether induction of TrkB and BDNF expression was unique to the hypoxic mouse model of $\mathrm{PH}$, we used monocrotaline-treated rats as an alternative $\mathrm{PH}$ model. Monocrotaline treatment up-regulated TrkB and BDNF mRNA in rat lung homogenate compared to control animals (Figure 2A). Induction was observed at later time points ( 28 days), correlating with progression of $\mathrm{PH}$. As observed in mouse lung sections, expression of TrkB and BDNF was detected in the pulmonary vasculature, whereas NT-4 was restricted to the bronchial epithelial layers (Figure 2B; see also Supplemental Figure S6 at http://ajp.amjpathol.org). Additionally, elevated expression of TrkB and BDNF was also observed in Su5416 rat model (Figure 2C). 
A

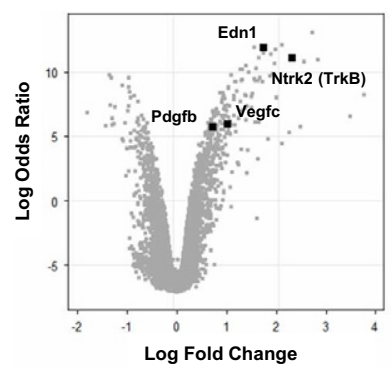

D
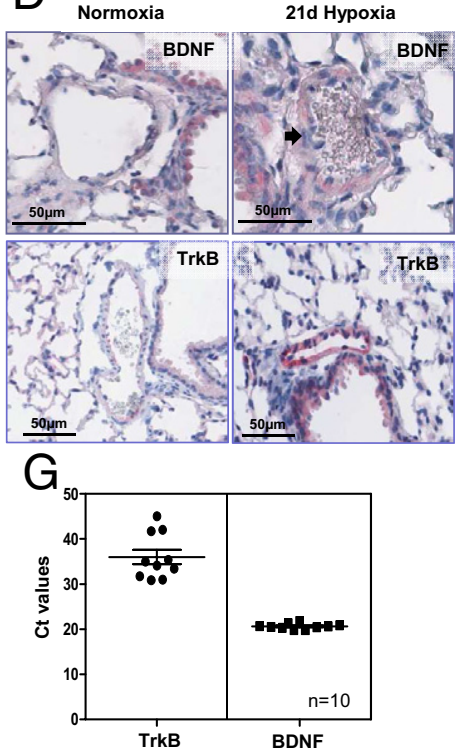

B

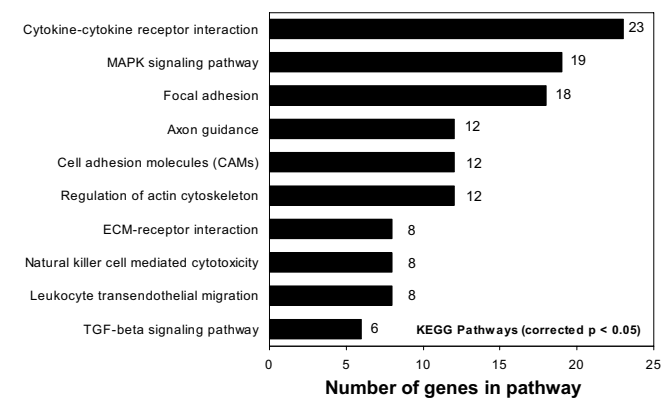

E
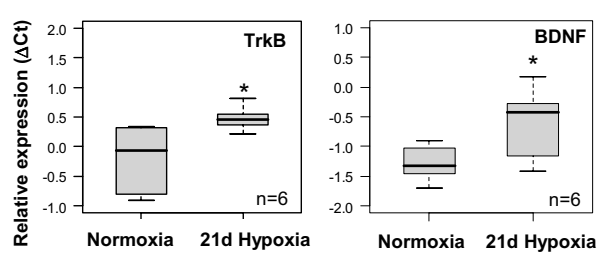

Normoxia 21d Hypoxia
C

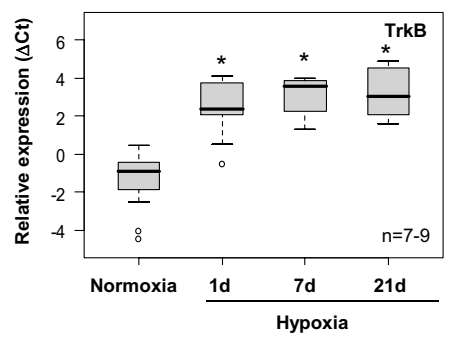

$\mathrm{F}$
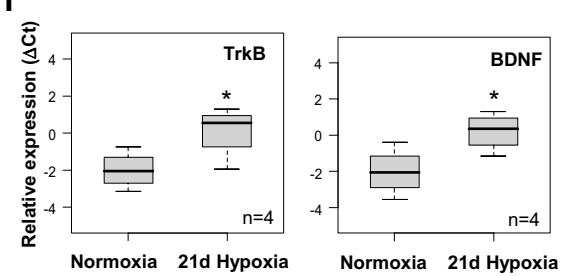

Figure 1. Ntrk2 is up-regulated in mouse lungs after 24 hours of hypoxia exposure $\left(\mathrm{pO}_{2}=0.01\right)$. Total RNA from mice lung homogenates was isolated ( $n=18$ per group), direct labeled, and hybridized to $44 \mathrm{~K} 60 \mathrm{mer}$ oligonucleotide microarrays (MWG). A: Volcano plot: $\log _{2}$-fold regulation compared to probability of regulation. Genes with $\log$ odds values $\geq 5$ were considered to be regulated; black spots, exemplary genes. B: Functional annotation of regulated genes was performed according to Gene Ontology (GO). Ntrk2 (TrkB) belongs to MAPK signaling pathway. C: A time course of TrkB expression was performed using real-time PCR of lung homogenates harvested 1, 7, or 21 days after hypoxia exposure ( $n=7$ to 9 , each). D: Immunohistochemical staining of TrkB and its ligand, BDNF in mouse lung sections. The arrow indicates positive staining. $\mathbf{E}$ and $\mathbf{F}$ : Real-time PCR analysis of TrkB and BDNF expression in (E) isolated major pulmonary arteries $(n=6)$, and (F) laser-microdissected intrapulmonary vessels ( 40 vessels per animal, $n=4$ ), from mice exposed to 21 days of hypoxia or normoxia. G: Expression levels of TrkB and BDNF in mouse PASMC as indicated by real-time PCR; lower $\mathrm{C}_{\mathrm{T}}$ values represent a more abundant transcript level. H: Immunofluorescence staining of TrkB and BDNF in mouse PASMC. The arrows indicate TrkB localization. Inset, negative control staining. ${ }^{*} P \leq 0.05$.

\section{TrkB and BDNF Expression in IPAH Patients}

We consequently examined the expression of TrkB and BDNF in IPAH patients. Similar to the hypoxia and monocrotaline models of $\mathrm{PH}$, expression of TrkB and BDNF localized to the pulmonary vasculature, specifically to the SMC layer as indicated by SMA immunoreactivity in adjacent sections (see Supplemental Figure S7 at $h t t p: / /$ ajp.amjpathol.org) and immunofluoresence (Figure 3A). Notably, TrkB and BDNF expression was observed in remodeled vessels of IPAH patients (Figure 3A; see also Supplemental Figure S7 at http://ajp.amjpathol.org). Laser microdissection in combination with real-time PCR verified increased expression of TrkB and BDNF in pulmonary arteries of IPAH patients compared to donors (Figure 3B). Furthermore, expression of TrkB and BDNF by SMCs was confirmed by real-time PCR and immunofluorescence staining of isolated human PASMC from donor lungs (Figure 3, C-E). Positive signal was also observed in PASMC from IPAH lungs (Figure 3D).

\section{BDNF Increases Proliferation of PASMC}

BDNF has previously been shown to increase the proliferation of neurons via the activation of TrkB receptor. ${ }^{33}$ Because SMC proliferation is one of the underlying mechanisms of vascular remodeling in $\mathrm{PH}$, we investigated whether BDNF can affect proliferation of SMCs. BDNF treatment resulted in a dose-dependent increase in proliferation (Figure $4 \mathrm{~A}$ ) and an abundance of the proliferation marker Ki-67 (Figure 4B). We next investigated BDNF effects on apoptosis. Interestingly, BDNF treatment did not alter PASMC apoptosis as determined by flow cytometry of Annexin V-labeled cells (Figure 4C) and by Western blot analysis of caspase-3 activation (Figure 4D). 
A

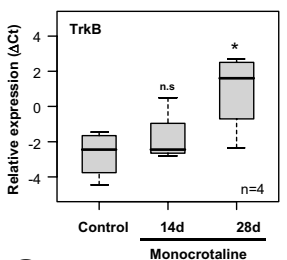

C

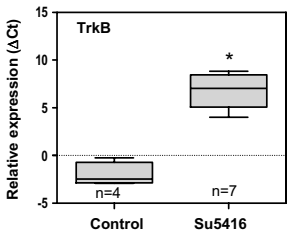

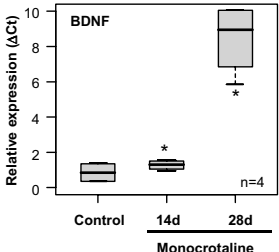

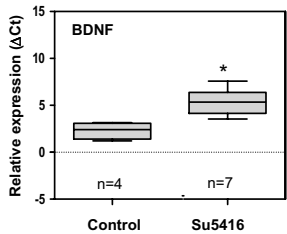

B control

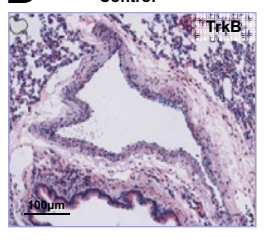

Monocrotaline

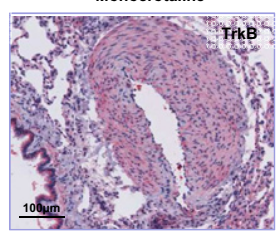

Control

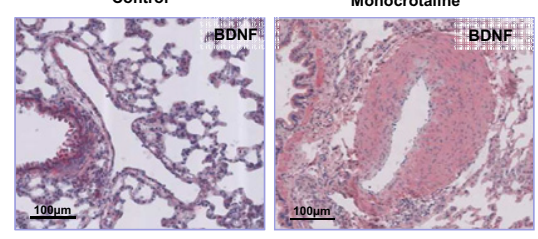

Figure 2. Analysis of TrkB and BDNF expression in rat PAH models. A: Real-time PCR analysis of TrkB and BDNF mRNA expression 14 and 28 days after monocrotaline administration $(n=4$ per group) in lung homogenates. B: Immunohistochemical staining of TrkB and BDNF in monocrotalinetreated lungs and lungs from control animals. C: Real-time PCR analysis of TrkB and BDNF mRNA expression in lung homogenates in the Su 5416 rat model ( $n=4$ controls, $n=7$ Su5416). n.s., not significant. ${ }^{*} P \leq 0.05$.

\section{BDNF Activates TrkB and MAPK Signaling Pathways in PASMC}

Next, we examined the effects of BDNF on intracellular signaling events, the activation of which could lead to proliferative response. BDNF treatment induced a rapid phosphorylation of the TrkB receptor within 1 minute of ligand application (see Supplemental Figure S8A at http://ajp.amjpathol.org). TrkB phosphorylation was accompanied by a strong time-dependent activation of ERK1/2, where phosphorylation occurred by 5 minutes and peaked at 15 minutes post stimulation (Figure 5A),
A

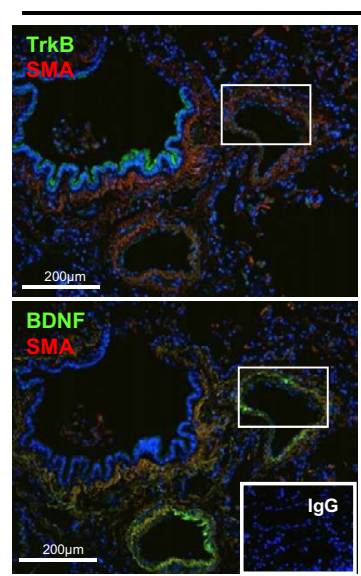

C

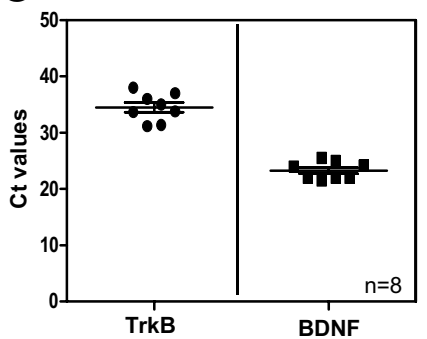

Donor

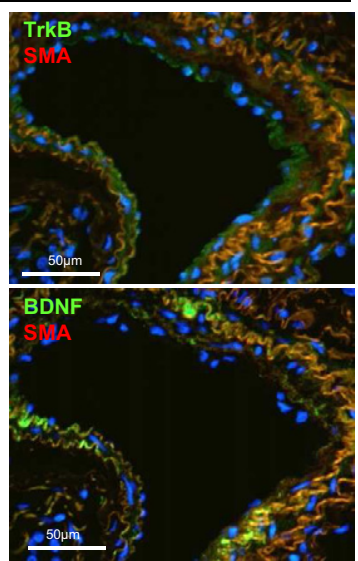

D

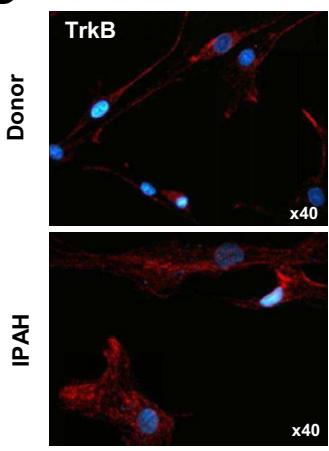

IPAH
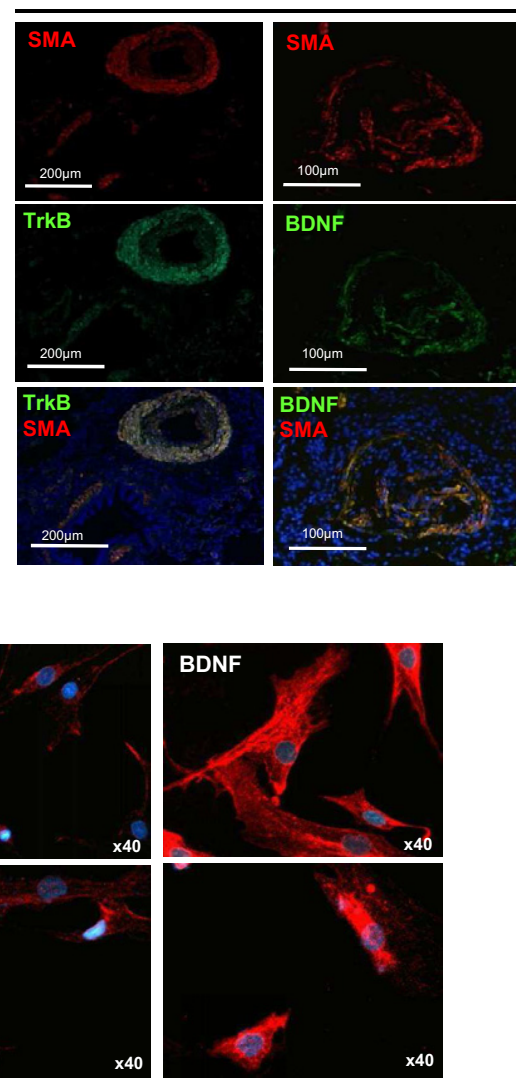

B

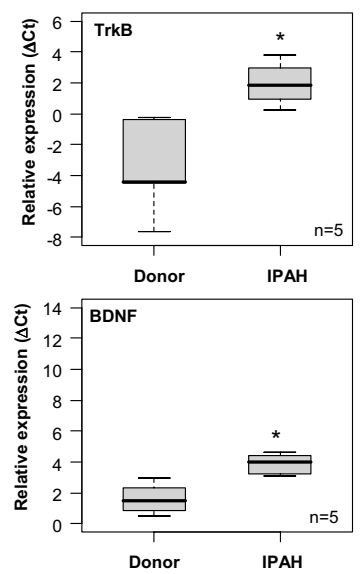

E
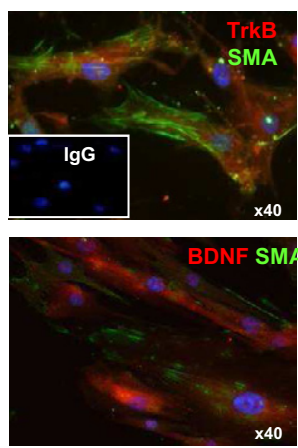

Figure 3. Up-regulation of TrkB and BDNF in human lung tissue from IPAH. A: Colocalization of BDNF and TrkB with SMA as indicated by immunofluorescence staining in donor and IPAH patients. B: Real-time PCR analysis of TrkB and BDNF in laser-microdissected intrapulmonary vessels from donor and IPAH patients. Expression is given in comparison to samples from donor lungs ( $n=5$ per group). C: Real-time PCR analysis of expression levels of TrkB and BDNF in human PASMC; lower $\mathrm{C}_{\mathrm{T}}$ values represent a more abundant transcript level. D: Immunofluorescence staining of TrkB and BDNF in human PASMC derived from donor and IPAH patients. E: Colocalization of BDNF and TrkB with SMA in PASMC as indicated by immunofluorescence staining, IgG, isotype control staining. ${ }^{*} P \leq 0.05$. 

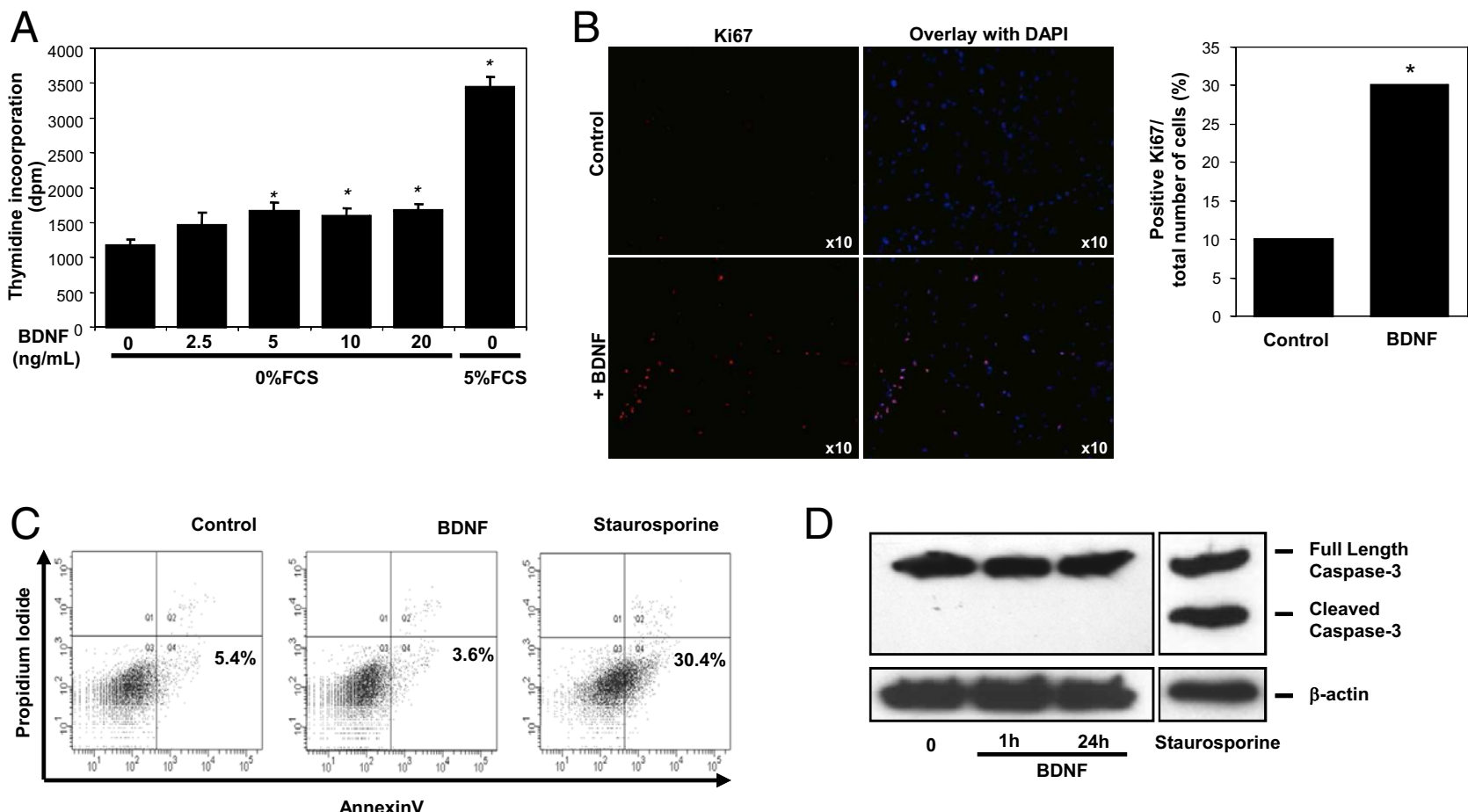

Figure 4. Functional role of TrkB and its ligand BDNF in remodeling. Proliferation after BDNF stimulation was assessed by direct $\left[{ }^{3} \mathrm{H}\right]$ thymidine incorporation (A) $(n=6)$, or immunofluorescence staining of Ki-67 proliferation marker $(\mathbf{B})$. The effect of BDNF on cell apoptosis was measured by annexin $\mathrm{V}$ staining $(\mathbf{C})$ and caspase-3 cleavage (D). 5\% FCS and staurosporine were used as positive controls for proliferation and apoptosis studies, respectively. ${ }^{*} P \leq 0.05$.

weak activation of AKT was also observed (see Supplemental Figure S8B at http://ajp.amjpathol.org). No significant activation of the p38 pathway was detected (see Supplemental Figure S8C at http://ajp.amjpathol.org). Specificity of TrkB and ERK1/2 activation was shown by pretreatment with the respective inhibitors $\mathrm{K} 252 \mathrm{a}$ and U0126, which attenuated phosphorylation of corresponding kinases (Figure 5, B and C). The specificity of BDNF/ TrkB/ERK1/2 dependent signaling was validated by the use of BDNF blocking antibodies. Following BDNF stimulation, decreased ERK1/2 phosphorylation was observed as compared to control treated cells. (Figure 5D).

\section{BDNF Induces Expression and DNA-Binding Activity of Egr-1 in Human PASMC}

To further investigate the effects of MAPK activation, we examined the ERK1/2 downstream signaling molecule, early growth response1 (Egr-1). Western blotting for Egr-1 revealed that after addition of BDNF to the PASMC, Egr-1 was rapidly and transiently induced with peak intensity at 6 hours after treatment, which decreased over time (Figure 6A). Additionally, immunofluorescence microscopy demonstrated a strong induction of Egr-1 expression and its accumulation in the nucleus of isolated
A

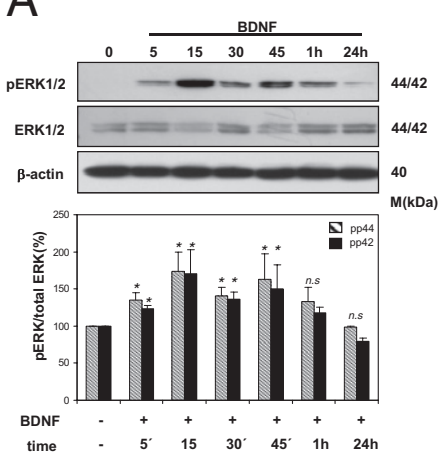

B

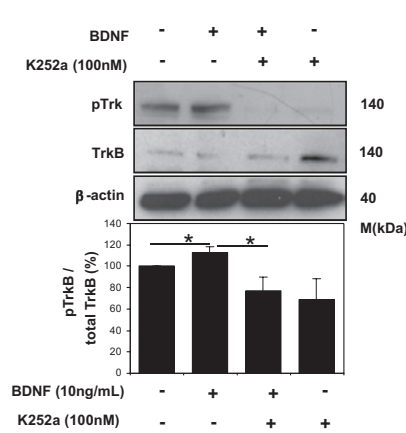

C

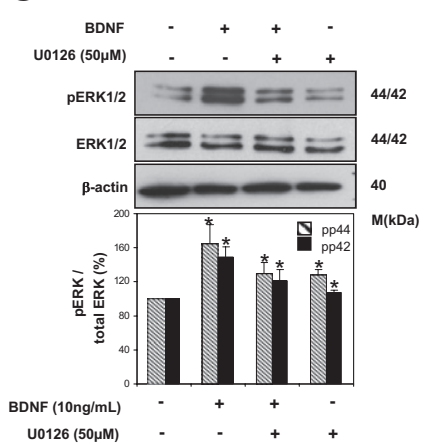

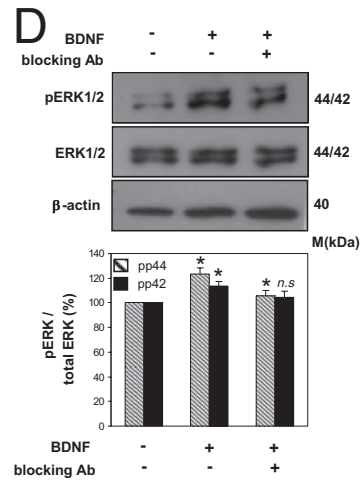

Figure 5. BDNF stimulation leads to MAP kinase activation. A: Time-dependent phosphorylation in response to BDNF of the ERK1/2 kinase with densitometric analysis. B and C: Effects on BDNF signaling by pretreatment with the inhibitors (B) K252a (TrkB) and (C) U0126 (ERK1/2) with densitometric analysis. Equal protein loading was confirmed by immunoblotting against $\beta$-actin. D: Effects of blocking BDNF antibody on ERK1/2 phosphorylation with densitometric analysis. $\mathrm{M}(\mathrm{kDa})$, molecular weight in kilodaltons; n.s., not significant. ${ }^{*} P \leq 0.05$. 
A

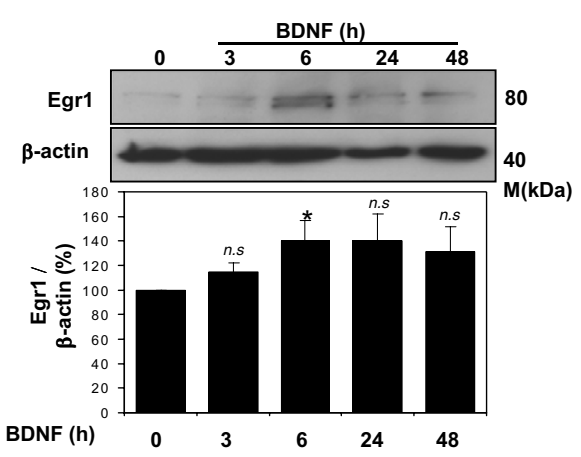

B
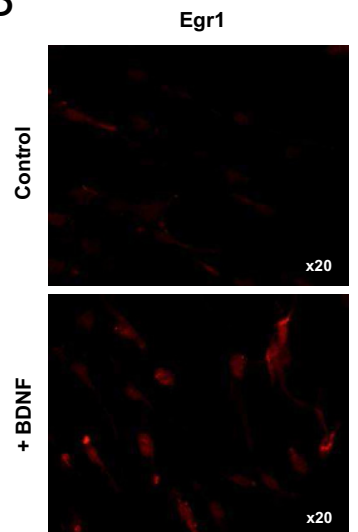
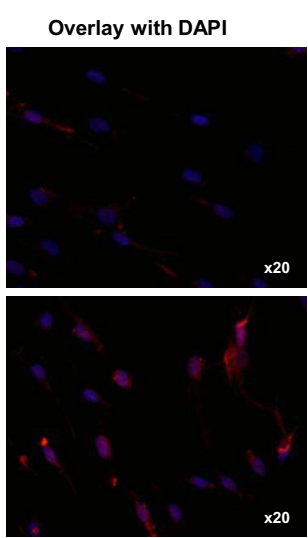

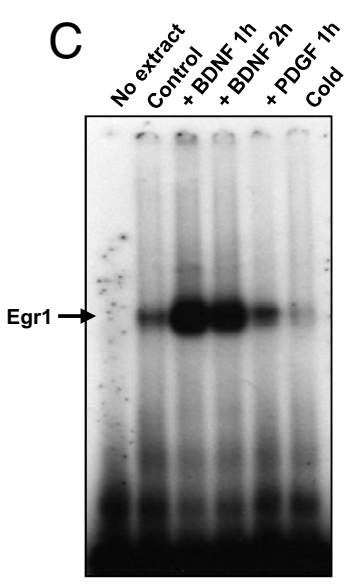

E
D

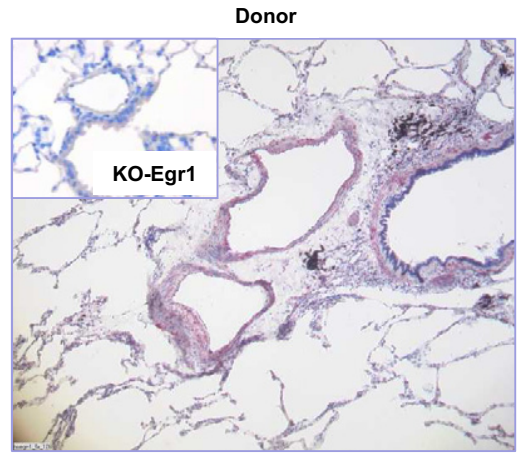

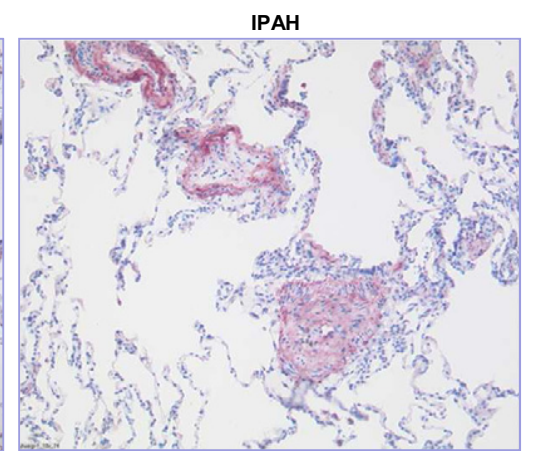

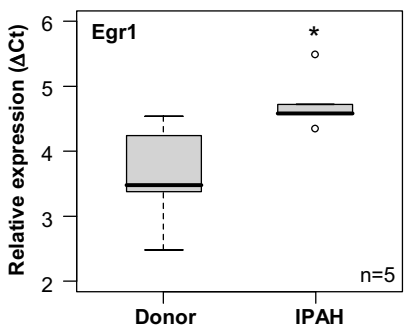

Figure 6. BDNF regulates and activates Egr-1. A: Induction of early growth-response factor 1 (Egr-1) protein in human PASMC as analyzed by Western blotting. B: BDNF-induced Egr-1 protein localization in PASMC as assessed by immunofluorescence analysis. C: Electrophoretic mobility shift assay for Egr-1 induction and DNA-protein interactions from nuclear extracts prepared from BDNF (10 ng/mL)-treated PASMC, incubated with radiolabeled oligonucleotide containing Egr-1 consensus sequence. Incubation with an excess (10-fold) of an unlabeled probe served as a control for specific binding. PDGF $(10 \mathrm{ng} / \mathrm{mL})$ treated cells served as a positive control. D: Egr-1 expression in lung parenchyma of donor and IPAH patients. An Eg $r-1^{-/}$mouse (KO-Egr-1) served as negative control. E: Real-time PCR analysis for Egr-1 expression in IPAH patient and donor laser-microdissected intrapulmonary vessels $(n=5)$. n.s., not significant. ${ }^{*} P \leq 0.05$.

human PASMC after BDNF stimulation (Figure 6B). The increased abundance of Egr-1 also correlated with enhanced and time-dependent DNA binding as shown by electrophoretic mobility shift assay, using the consensus sequence GCGGGGGCG for Egr-1 transcription factor (Figure 6C).

\section{Egr-1 Expression in IPAH Patients}

Interestingly, we could also observe intense immunohistochemical staining of Egr-1 in vessels of IPAH and donor lungs. Notably, intense staining for Egr-1 was observed in remodeled arteries of IPAH patients. Staining of adjacent sections for SMA further confirmed predominant Egr-1 expression in SMC (Figure 6D; see also Supplemental Figure S9 at http://ajp.amjpathol. org). In line with these results, microdissected pulmonary vessels from IPAH lungs revealed significantly elevated Egr-1 mRNA levels compared to donor lungs (Figure 6E).

\section{Egr-1 Regulates Expression of Downstream}

\section{Genes}

Subsequently, to determine whether the BDNF-induced activation of Egr-1 leads to downstream gene activation, we investigated expression levels of genes known to contain Egr-1 binding sites and have a potential role in remodeling processes. Real-time PCR analysis of cyclin D1 and fibronectin expression showed up-regulation in response to BDNF stimulation (Figure 7A). Moreover, BDNF induced the mRNA expression of Egr-1 transcription factor. Addition of either U0126 or K252a inhibitors, abolished the BDNF-induced up-regulation, and in the case of Egr-1, decreased expression to unstimulated levels (Figure 7A).

\section{BDNF Leads to Proliferation of Human PASMC via ERK and Egr-1}

Next, we examined whether inhibition of TrkB or MAPK phosphorylation and its downstream transcription factor, Egr-1, can inhibit the proproliferative effect of BDNF. Pre incubation with $\mathrm{K} 252 \mathrm{a}$ or U0126 inhibitors attenuated the BDNF-induced proliferation of PASMC (Figure 7B). Moreover, knockdown of Egr-1 by the application of Egr-1specific siRNA blocked the BDNF proproliferative effects (Figure 7C). The efficiency of siRNA knockdown was assessed by real-time PCR analysis (see Supplemental Figure S10 at http://ajp.amjpathol.org). 

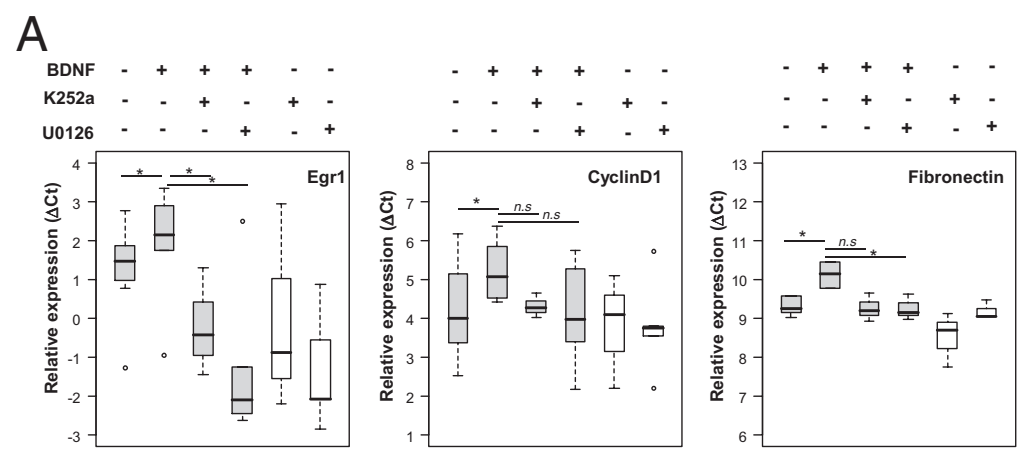

$\mathrm{B}$
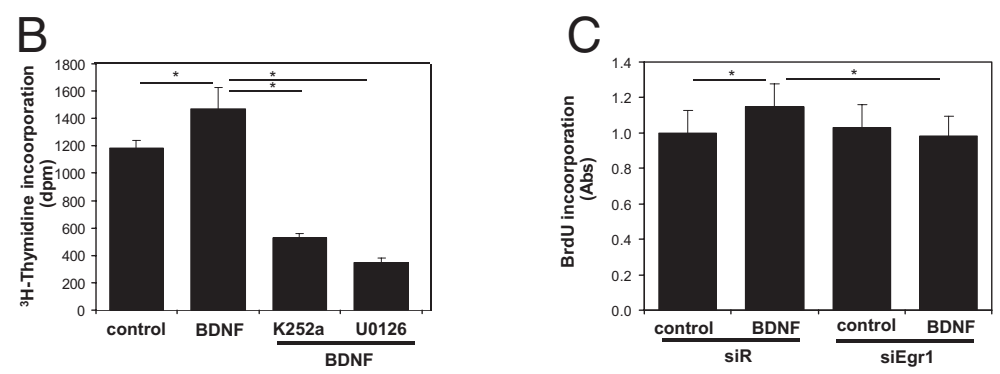

Figure 7. BDNF-induced proliferation in human PASMC associates with an activation of MAP kinases and Egr-1. A: Consequence of BDNF $(10 \mathrm{ng} / \mathrm{mL})$ treatment on expression of Egr-1, cyclin D1, and fibronectin in the presence of K252a (TrkB inhibitor) and U0126 (ERK inhibitor), as assessed by real-time PCR $(n=3)$. Effects of (B) K252a and U0126 and (C) Egr-1 knockdown, on BDNF-induced proliferation in human primary PASMC as determined by direct $\left[{ }^{3} \mathrm{H}\right]$ thymidine or bromodeoxyuridine incorporation $(n=3)$. n.s., not significant. ${ }^{*} P \leq 0.05$

\section{Discussion}

In this study, we initially investigated changes in the mRNA expression profiles arising from short exposure of mice to hypoxia (24 hours). Analysis of this time point, when remodeling processes are instigated but not fully established, could potentially identify key triggers of vascular remodeling. Already at this early time point, the majority of regulated genes were involved in processes related to differentiation and matrix remodeling (focal adhesion, cell adhesion, regulation of actin cytoskeleton, and extracellular matrix receptor interaction). Other significantly up-regulated genes included several that encode growth factors known to be involved in vascular remodeling, namely PDGFb and Edn1, confirming previous studies. ${ }^{34,35}$ Together, this demonstrates that already after a short exposure to hypoxia, many genes involved in vascular remodeling are regulated. In addition to growth factors, altered expression of different tyrosine receptors has also been documented to play an important role in hypoxia-induced and nonhypoxic models of vascular remodeling. ${ }^{7,10}$ In our study, the strongest up-regulated tyrosine kinase receptor was TrkB, encoded by the gene Ntrk2. High TrkB expression was maintained throughout prolonged hypoxia (7 and 21 days), even when vascular remodeling processes are considered to be fully established. ${ }^{22}$ Moreover, on re-exposure to normoxia (reverse remodeling), TrkB expression was attenuated (unpublished observations). Oxygen-dependent regulation of TrkB has been described in neuroblastoma cells; transcription of the Ntrk2 gene is stimulated at low oxygen tension through a HIF1-dependent mechanism. ${ }^{36}$ Similarly in our study, hypoxia exposure led to an up-regulation of TrkB in mouse lung homogenates and isolated pulmonary arteries. However, this is the first report to describe the role of TrkB in association with $\mathrm{PH}$.

The Trk receptor tyrosine kinase family is selectively activated by distinct growth factors: nerve growth factor (NGF) activates TrkA; BDNF and NT-4, TrkB; and NT-3, TrkC. ${ }^{33}$ TrkB and its two ligands, BDNF and NT-4, were initially characterized as factors that regulate development, differentiation and survival of neurons. ${ }^{33}$ Their expression has since been detected in nonneuronal cells, particularly in human and rat vascular SMCs, endothelial cells, skeletal muscle cells, and great vessels from late gestation through to adulthood. ${ }^{23,24}$ In human lung tissue, we localized TrkB and BDNF protein expression to the bronchial epithelial layer and SMCs of pulmonary arteries. Expression of TrkB and BDNF by SMCs was further validated by immunofluorescence staining of isolated human PASMC from donor and IPAH patients. By contrast, NT-4 was mostly restricted to bronchial and alveolar epithelial cells, and therefore, we concluded a subordinate role of this ligand in vascular remodeling. Accordingly, we have recently shown the importance of NT-4 in the pathogenesis of pulmonary fibrosis, and its critical role in alveolar epithelial cells and fibroblasts proliferation, ${ }^{37}$ supporting the importance of neurotrophins and their receptors in pulmonary diseases.

In our study, we found increased expression of TrkB and BDNF in three different animal models of $\mathrm{PH}$, namely, the hypoxic mouse model, monocrotalinetreated rats, and Su5416-treated rats. The latter is especially important as rats treated with Su5416 in combination with hypoxia are currently regarded as the most accurate representation of human PAH and display many hallmarks of the human disease. Furthermore, we were able to independently show that the mRNA levels of both molecules were increased in iso- 
lated pulmonary arteries and laser-microdissected intrapulmonary vessels. Finally, we demonstrated an in vitro role of BDNF/TrkB in PASMC by regulating proliferation, a process that is important in vascular remodeling. Altogether, our data strongly imply a role for the $\mathrm{BDNF} / \mathrm{TrkB}$ axis in the pathogenesis of $\mathrm{PH}$.

Interestingly, the higher expression of BDNF during later stages of vascular remodeling in all experimental models and also in IPAH patients indicates that disease progression could be enhanced by up-regulation of both the receptor and ligand. We cannot exclude the involvement of other factors in addition to hypoxia in regulating $\mathrm{BDNF} / T r k B$, especially in inflammatory models where many different growth factors are released.

BDNF and TrkB have previously been described to be involved in other vascular diseases and disease models. Enhanced BDNF levels were observed in macrophages and SMCs of atherosclerotic coronary arteries. ${ }^{23,38}$ In the rat aortic balloon deendothelialization model of vascular injury, expression of BDNF and TrkB are both increased dramatically in the area of injury within 3 days and persist during the formation of the neointima. ${ }^{23}$ Thus, local secretion of neurotrophins in the developing neointima may serve to promote vascular SMC accumulation or activation, thereby promoting atherogenesis. ${ }^{23,39}$ Increased neovascularization could be observed following adenoviral BDNF delivery in mice and also in the vicinity of foam plugs in rats. ${ }^{40,41} \mathrm{~A}$ role of BDNF in angiogenesis is further supported by observations in $B D N F^{-\prime-}$ mice, which suffer from destabilization of the myocardial vessel wall, leading to intraventricular hemorrhage and early postnatal lethality. ${ }^{24}$ Similarly, TrkB ${ }^{-1-}$ mice show a marked reduction in blood vessel formation in the subepicardial region and suffer from an early postnatal lethality. ${ }^{42}$ Taken together, these findings suggest a marked role of BDNF and TrkB in angiogenesis and imply that altered expression of either ligand and/or receptor can facilitate pathogenesis.

In neuroblastoma, the BDNF/TrkB signaling cascade acts in a cell-protective and anti-apoptotic (proliferative) manner. ${ }^{43}$ Similarly, we could demonstrate that BDNF is an important proproliferative factor for PASMC. On ligand binding, TrkB receptors dimerize and autophosphorylate their specific tyrosine residues, thereby activating intracellular signaling cascades. ${ }^{44}$ BDNF stimulation of human PASMC activated the prosurvival ERK1/2 and AKT pathways, induced expression of downstream genes including Egr-1, cyclin D1, and fibronectin. The importance of extracellular matrix components, such as fibronectin, in remodeling processes has been well documented, ${ }^{22,45}$ whereas cyclin D1 is a well-described mediator of cell proliferation. ${ }^{25,46}$ As the promoter of both genes contain Egr-1 binding sites, ${ }^{47,48}$ this suggests that their regulation in PASMC might be Egr-1 dependent. This is in line with previous findings showing Egr-1-dependent regulation of fibronectin and cyclin D1 in mouse lung fibroblasts. ${ }^{46,49}$ Other stimuli known to induce Egr-1, fibronectin, or cyclin D1 expression include mechanical forces, reactive oxygen species, PDGF, EGF, and FGF, ${ }^{50,51}$ all of which have been implicated in the pathogenesis of $\mathrm{PH}$. Moreover, Egr-1 can also regulate BDNF and PDGF expression, ${ }^{52}$ which could result in a positive feedback loop and potentiate pathogenesis. Strong expression of Egr-1 was observed in the smooth muscle layer of intrapulmonary arteries in human lung sections, and was even more pronounced in remodeled arteries of IPAH patients. This observation was further validated by laser microdissection in combination with real-time PCR analysis. Our findings indicate that BDNF/TrkB signaling induces proliferation of PASMC in IPAH patients via Egr-1.

Furthermore, K252a and U0126 suppressed the BDNF-induced proliferation of PASMC, underlining the importance of BDNF/TrkB/ERK signaling in vascular remodeling processes. K252a has been already described as an antiproliferative factor in angiogenesis and reduces blood vessel formation in Matrigel (BD Biosciences). ${ }^{53,54}$ However, further studies should be performed to determine whether application of the inhibitor attenuates or even reverses $\mathrm{PH}$ in vivo.

Taken together, our results show for the first time that the BDNF/TrkB/ERK $1 / 2$ pathway is up-regulated during vascular remodeling and that elevated expression of these genes leads to a proproliferative effect and correlates with disease progression. Inhibition of this signaling cascade was able to attenuate SMC proliferation and may thus present an interesting new intervention approach in pulmonary hypertension.

\section{Acknowledgments}

We thank Miriam Wessendorf, Karin Quanz, and Ida Niklasson for excellent technical assistance, Dr. Patrick Charnay for the Egr-1 knockout mice, and Walter Klepetko (University of Vienna, Vienna, Austria) for providing human lung material.

\section{References}

1. Badesch DB, Champion HC, Sanchez MA, Hoeper MM, Loyd JE, Manes A, McGoon M, Naeije R, Olschewski H, Oudiz RJ, Torbicki A: Diagnosis and assessment of pulmonary arterial hypertension. J Am Coll Cardiol 2009, 54:S55-S66

2. Hoeper MM, Barbera JA, Channick RN, Hassoun PM, Lang IM, Manes A, Martinez FJ, Naeije R, Olschewski H, Pepke-Zaba J, Redfield MM, Robbins IM, Souza R, Torbicki A, McGoon M: Diagnosis, assessment, and treatment of non-pulmonary arterial hypertension pulmonary hypertension. J Am Coll Cardiol 2009, 54:S85-S96

3. Simonneau G, Robbins IM, Beghetti M, Channick RN, Delcroix M, Denton CP, Elliott CG, Gaine SP, Gladwin MT, Jing ZC, Krowka MJ, Langleben D, Nakanishi N, Souza R: Updated clinical classification of pulmonary hypertension. J Am Coll Cardiol 2009, 54:S43-S54

4. Hassoun PM, Mouthon L, Barbera JA, Eddahibi S, Flores SC, Grimminger F, Jones PL, Maitland ML, Michelakis ED, Morrell NW, Newman JH, Rabinovitch M, Schermuly R, Stenmark KR, Voelkel NF, Yuan JX, Humbert M: Inflammation, growth factors, and pulmonary vascular remodeling. J Am Coll Cardiol 2009, 54:S10-S19

5. Machado RD, Aldred MA, James V, Harrison RE, Patel B, Schwalbe EC, Gruenig E, Janssen B, Koehler R, Seeger W, Eickelberg O, Olschewski H, Elliott CG, Glissmeyer E, Carlquist J, Kim M, Torbicki A, Fijalkowska A, Szewczyk G, Parma J, Abramowicz MJ, Galie N, Morisaki H, Kyotani S, Nakanishi N, Morisaki T, Humbert M, Simonneau G, Sitbon O, Soubrier F, Coulet F, Morrell NW, Trembath RC: 
Mutations of the TGF-beta type II receptor BMPR2 in pulmonary arterial hypertension. Hum Mutat 2006, 27:121-132

6. Thomson JR, Machado RD, Pauciulo MW, Morgan NV, Humbert M, Elliott GC, Ward K, Yacoub M, Mikhail G, Rogers P, Newman J, Wheeler L, Higenbottam T, Gibbs JS, Egan J, Crozier A, Peacock A, Allcock R, Corris P, Loyd JE, Trembath RC, Nichols WC: Sporadic primary pulmonary hypertension is associated with germline mutations of the gene encoding BMPR-II, a receptor member of the TGFbeta family. J Med Genet 2000, 37:741-745

7. Schermuly RT, Dony E, Ghofrani HA, Pullamsetti S, Savai R, Roth M, Sydykov A, Lai YJ, Weissmann N, Seeger W, Grimminger F: Reversal of experimental pulmonary hypertension by PDGF inhibition. J Clin Invest 2005, 115:2811-2821

8. Humbert M, Monti G, Fartoukh M, Magnan A, Brenot F, Rain B, Capron F, Galanaud P, Duroux P, Simonneau G, Emilie D: Plateletderived growth factor expression in primary pulmonary hypertension: comparison of HIV seropositive and HIV seronegative patients. Eur Respir J 1998, 11:554-559

9. Benisty JI, McLaughlin VV, Landzberg MJ, Rich JD, Newburger JW, Rich S, Folkman J: Elevated basic fibroblast growth factor levels in patients with pulmonary arterial hypertension. Chest 2004, 126:12551261

10. Merklinger SL, Jones PL, Martinez EC, Rabinovitch M: Epidermal growth factor receptor blockade mediates smooth muscle cell apoptosis and improves survival in rats with pulmonary hypertension. Circulation 2005, 112:423-431

11. Yu Y, Sweeney M, Zhang S, Platoshyn O, Landsberg J, Rothman A, Yuan JX: PDGF stimulates pulmonary vascular smooth muscle cell proliferation by upregulating TRPC6 expression. Am J Physiol Cell Physiol 2003, 284:C316-C330

12. Balasubramaniam V, Le Cras TD, Ivy DD, Grover TR, Kinsella JP, Abman SH: Role of platelet-derived growth factor in vascular remodeling during pulmonary hypertension in the ovine fetus. Am J Physiol Lung Cell Mol Physiol 2003, 284:L826-L833

13. Ghofrani HA, Seeger W, Grimminger F: Imatinib for the treatment of pulmonary arterial hypertension. N Engl J Med 2005, 353:1412-1413

14. Weissmann N, Sommer N, Schermuly RT, Ghofrani HA, Seeger W, Grimminger F: Oxygen sensors in hypoxic pulmonary vasoconstriction. Cardiovasc Res 2006, 71:620-629

15. Beppu H, Ichinose F, Kawai N, Jones RC, Yu PB, Zapol WM, Miyazono K, Li E, Bloch KD: BMPR-Il heterozygous mice have mild pulmonary hypertension and an impaired pulmonary vascular remodeling response to prolonged hypoxia. Am J Physiol Lung Cell Mol Physiol 2004, 287:L1241-L1247

16. Fike CD, Zhang Y, Kaplowitz MR: Thromboxane inhibition reduces an early stage of chronic hypoxia-induced pulmonary hypertension in piglets. J Appl Physiol 2005, 99:670-676

17. Smirnov SV, Robertson TP, Ward JP, Aaronson PI: Chronic hypoxia is associated with reduced delayed rectifier $\mathrm{K}+$ current in rat pulmonary artery muscle cells. Am J Physiol 1994, 266:H365-H370

18. Hong Z, Weir EK, Nelson DP, Olschewski A: Subacute hypoxia decreases voltage-activated potassium channel expression and function in pulmonary artery myocytes. Am J Respir Cell Mol Biol 2004, 31:337-343

19. Semenza G: Signal transduction to hypoxia-inducible factor 1 . Biochem Pharmacol 2002, 64:993-998

20. Wenger RH: Cellular adaptation to hypoxia: O2-sensing protein hydroxylases, hypoxia-inducible transcription factors, and O2-regulated gene expression. FASEB J2002, 16:1151-1162

21. Semenza GL: Oxygen-regulated transcription factors and their role in pulmonary disease. Respir Res 2000, 1:159-162

22. Kwapiszewska G, Wilhelm J, Wolff S, Laumanns I, Koenig IR, Ziegler A, Seeger W, Bohle RM, Weissmann N, Fink L: Expression profiling of laser-microdissected intrapulmonary arteries in hypoxia-induced pulmonary hypertension. Respir Res 2005, 6:109

23. Donovan MJ, Miranda RC, Kraemer R, McCaffrey TA, Tessarollo L, Mahadeo D, Sharif S, Kaplan DR, Tsoulfas P, Parada L, et al.: Neurotrophin and neurotrophin receptors in vascular smooth muscle cells. Regulation of expression in response to injury. Am J Pathol 1995; 147:309-324

24. Donovan MJ, Lin MI, Wiegn P, Ringstedt T, Kraemer R, Hahn R, Wang S, Ibanez CF, Rafii S, Hempstead BL: Brain derived neurotrophic factor is an endothelial cell survival factor required for intramyocardial vessel stabilization. Development 2000, 127:4531-4540
25. Kwapiszewska G, Wygrecka M, Marsh LM, Schmitt S, Trosser R, Wilhelm J, Helmus K, Eul B, Zakrzewicz A, Ghofrani HA, Schermuly RT, Bohle RM, Grimminger F, Seeger W, Eickelberg O, Fink L, Weissmann N: Fhl-1, a new key protein in pulmonary hypertension. Circulation 2008, 118:1183-1194

26. R Development Core Team: R: A language and environment for statistical computing. Vienna, Austria, R Foundation for Statistical Computing, 2006

27. Smyth GK, Speed T: Normalization of cDNA microarray data. Methods 2003, 31:265-273

28. Khatri P, Bhavsar P, Bawa G, Draghici S: Onto-Tools: an ensemble of web-accessible, ontology-based tools for the functional design and interpretation of high-throughput gene expression experiments. Nucleic Acids Res 2004, 32:W449-W456

29. Taraseviciene-Stewart L, Kasahara Y, Alger L, Hirth P, Mc Mahon G, Waltenberger J, Voelkel NF, Tuder RM: Inhibition of the VEGF receptor 2 combined with chronic hypoxia causes cell death-dependent pulmonary endothelial cell proliferation and severe pulmonary hypertension. FASEB J 2001, 15:427-438

30. Dumitrascu R, Weissmann N, Ghofrani HA, Dony E, Beuerlein K Schmidt H, Stasch JP, Gnoth MJ, Seeger W, Grimminger F, Schermuly RT: Activation of soluble guanylate cyclase reverses experimental pulmonary hypertension and vascular remodeling. Circulation 2006, 113:286-295

31. Kwapiszewska G, Markart P, Dahal BK, Kojonazarov B, Marsh LM, Schermuly RT, Taube C, Meinhardt A, Ghofrani HA, Steinhoff M, Seeger W, Preissner KT, Olschewski A, Weissmann N, Wygrecka M: PAR-2 inhibition reverses experimental pulmonary hypertension. Circ Res 2012, 110:1179-1191

32. Schermuly RT, Pullamsetti SS, Kwapiszewska G, Dumitrascu R, Tian X, Weissmann N, Ghofrani HA, Kaulen C, Dunkern T, Schudt C Voswinckel R, Zhou J, Samidurai A, Klepetko W, Paddenberg R, Kummer W, Seeger W, Grimminger F: Phosphodiesterase 1 upregulation in pulmonary arterial hypertension: target for reverse-remodeling therapy. Circulation 2007, 115:2331-2339

33. Barbacid M: The Trk family of neurotrophin receptors. J Neurobiol 1994, 25:1386-1403

34. Berg JT, Breen EC, Fu Z, Mathieu-Costello O, West JB: Alveolar hypoxia increases gene expression of extracellular matrix proteins and platelet-derived growth factor-B in lung parenchyma. Am J Respir Crit Care Med 1998, 158:1920-1928

35. Kourembanas S, Marsden PA, McQuillan LP, Faller DV: Hypoxia induces endothelin gene expression and secretion in cultured human endothelium. J Clin Invest 1991, 88:1054-1057

36. Martens LK, Kirschner KM, Warnecke C, Scholz H: Hypoxia-inducible factor-1 (HIF-1) is a transcriptional activator of the TrkB neurotrophin receptor gene. J Biol Chem 2007, 282:14379-14388

37. Avcuoglu S, Wygrecka M, Marsh LM, Gunther A, Seeger W, Weissmann N, Fink L, Morty RE, Kwapiszewska G: The TrkB/NT4 signaling axis is perturbed in clinical and experimental pulmonary fibrosis. Am J Respir Cell Mol Biol 2011, 45:768-780

38. Ejiri J, Inoue N, Kobayashi S, Shiraki R, Otsui K, Honjo T, Takahashi M, Ohashi Y, Ichikawa S, Terashima M, Mori T, Awano K, Shinke T, Shite J, Hirata K, Yokozaki H, Kawashima S, Yokoyama M: Possible role of brain-derived neurotrophic factor in the pathogenesis of coronary artery disease. Circulation 2005, 112:2114-2120

39. Kraemer R, Nguyen $H$, March KL, Hempstead B: NGF activates similar intracellular signaling pathways in vascular smooth muscle cells as PDGF-BB but elicits different biological responses. Arterioscler Thromb Vasc Biol 1999, 19:1041-1050

40. Kermani P, Rafii D, Jin DK, Whitlock P, Schaffer W, Chiang A, Vincent L, Friedrich M, Shido K, Hackett NR, Crystal RG, Rafii S, Hempstead BL: Neurotrophins promote revascularization by local recruitment of TrkB + endothelial cells and systemic mobilization of hematopoietic progenitors. J Clin Invest 2005, 115:653-663

41. Patist CM, Mulder MB, Gautier SE, Maquet V, Jerome R, Oudega M: Freeze-dried poly(D,L-lactic acid) macroporous guidance scaffolds impregnated with brain-derived neurotrophic factor in the transected adult rat thoracic spinal cord. Biomaterials 2004, 25:1569-1582

42. Wagner N, Wagner KD, Theres H, Englert C, Schedl A, Scholz H: Coronary vessel development requires activation of the TrkB neurotrophin receptor by the Wilms' tumor transcription factor Wt1. Genes Dev 2005, 19:2631-2642 
43. Schramm A, Schulte JH, Astrahantseff K, Apostolov O, Limpt V, Sieverts H, Kuhfittig-Kulle S, Pfeiffer P, Versteeg R, Eggert A: Biological effects of TrkA and TrkB receptor signaling in neuroblastoma Cancer Lett 2005, 228:143-153

44. Huang EJ, Reichardt LF: Trk receptors: roles in neuronal signal transduction. Annu Rev Biochem 2003, 72:609-642

45. Hornberger LK, Singhroy S, Cavalle-Garrido T, Tsang W, Keeley F, Rabinovitch M: Synthesis of extracellular matrix and adhesion through beta(1) integrins are critical for fetal ventricular myocyte proliferation. Circ Res 2000, 87:508-515

46. Banks MF, Gerasimovskaya EV, Tucker DA, Frid MG, Carpenter TC, Stenmark KR: Egr-1 antisense oligonucleotides inhibit hypoxia-induced proliferation of pulmonary artery adventitial fibroblasts. J Appl Physiol 2005, 98:732-738

47. Liu C, Yao J, de Belle I, Huang RP, Adamson E, Mercola D: The transcription factor EGR-1 suppresses transformation of human fibrosarcoma HT1080 cells by coordinated induction of transforming growth factor-beta1, fibronectin, and plasminogen activator inhibitor-1. J Biol Chem 1999, 274:4400-4411

48. Yan $Y X$, Nakagawa $H$, Lee MH, Rustgi AK: Transforming growth factor-alpha enhances cyclin D1 transcription through the binding of early growth response protein to a cis-regulatory element in the cyclin D1 promoter. J Biol Chem 1997, 272:33181-33190

49. Yasuoka H, Hsu E, Ruiz XD, Steinman RA, Choi AM, Feghali-Bostwick CA: The fibrotic phenotype induced by IGFBP-5 is regulated by
MAPK activation and egr-1-dependent and -independent mechanisms. Am J Pathol 2009, 175:605-615

50. Silverman ES, Khachigian LM, Lindner V, Williams AJ, Collins T: Inducible PDGF A-chain transcription in smooth muscle cells is mediated by Egr-1 displacement of Sp1 and Sp3. Am J Physiol 1997, 273:H1415-H1426

51. Hjoberg J, Le L, Imrich A, Subramaniam V, Mathew SI, Vallone J, Haley KJ, Green FH, Shore SA, Silverman ES: Induction of early growth-response factor 1 by platelet-derived growth factor in human airway smooth muscle. Am J Physiol Lung Cell Mol Physiol 2004, 286:L817-L825

52. Fu M, Zhang J, Lin Y, Zhu X, Ehrengruber MU, Chen YE: Early growth response factor- 1 is a critical transcriptional mediator of peroxisome proliferator-activated receptor-gamma 1 gene expression in human aortic smooth muscle cells. J Biol Chem 2002, 277:26808-26814

53. Cantarella G, Lempereur L, Presta M, Ribatti D, Lombardo G, Lazarovici P, Zappala G, Pafumi C, Bernardini R: Nerve growth factorendothelial cell interaction leads to angiogenesis in vitro and in vivo. FASEB J 2002, 16:1307-1309

54. Park MJ, Kwak HJ, Lee HC, Yoo DH, Park IC, Kim MS, Lee SH, Rhee $\mathrm{CH}$, Hong SI: Nerve growth factor induces endothelial cell invasion and cord formation by promoting matrix metalloproteinase-2 expression through the phosphatidylinositol 3-kinase/Akt signaling pathway and AP-2 transcription factor. J Biol Chem 2007, 282:30485-30496 